\title{
A Recognition Model of National Legal Pluralism in a Unitary State through the Prismatic Theory Approach
}

\author{
Jati Nugroho \\ STIH Jenderal Sudirman, Lumajang \\ e-mail: thomasjatinugroho@gmail.com
}

\begin{tabular}{l}
\hline \multicolumn{1}{c}{ Article Info } \\
\hline Keyword: \\
National Legal Pluralism; \\
Unitary State; \\
Prismatic Theory \\
Approach.
\end{tabular}

Abstract

The choice of a unitary state based on Article 1 Section 1 of the 1945 Constitution theoretically always relates to the factor of equality within the state. However, the choice of the Republic of Indonesia as a unitary state is based on the consideration of the pluralism aspects in terms of culture, language, customs, and ethnicity, which brings consequences for the recognition of applicable legal pluralism (Article 18B Section 2 of the 1945 Constitution). This study examines legal pluralism in a unitary state based on the prismatic theory approach to find out its legal recognition model.

This study aims to find an ideal legal pluralism recognition model in a unitary state that has tended to be centralized, such as implementing the Basic Agrarian Law that ignores the customary

laws. The results of the legal prismatic theory approach are expected to able to fulfill justice in a pluralistic society. The researcher employed a normative juridical method through a politicallaw approach to various laws and regulations in this study. Furthermore, the researcher also used a qualitative analysis.

The results of this study showed as follows. (1) Politics of law as a guideline for legal development is inconsistent with Pancasila and legal systems that accommodate legal pluralism. As a result, customary law must comply with national law, which recognizes weak legal pluralism. (2) The recognition model of national legal pluralism through the prismatic theory approach by considering the plurality of the prevailing legal order may create certainty and benefit on the value of justice in society according to national ideology and Pancasila as the soul of the nation.

The recommendations of this study are as follows. (1) Legal development should use the recognition model of national legal pluralism through the prismatic theory approach so that certainty and benefit on the value of justice in society can be established according to national ideology and Pancasila as the soul of the nation. (2) The prismatic theory approach can be an alternative solution to the recognition model of legal pluralism in realizing Indonesian national law based on Pancasila as the ideology and spirit of the nation.

Article Info

\author{
Kata Kunci: \\ Pluralisme Hukum \\ Nasional; \\ Negara Kesatuan; \\ Pendekatan Teori \\ Prismatik;
}

Abstrak
Pilihan bentuk negara kesatuan sesuai Pasal 1 ayat (1) UUD 1945
secara teori umumnya selalu dikaitkan unsur persamaan dalam negara.
Namun pilihan negara Indonesia sebagai negara kesatuan justru
terdapat kemajemukan baik aspek budaya, bahasa, adat istiadat dan
suku bangsa yang membawa konsekuensi adanya pengakuan
pluralisme hukum yang berlaku (Pasal 18B ayat (2) UUD 1945).
Riset ini menganalisis pluralisme hukum dalam negara kesatuan
kaitannya dengan pendekatan Teori Prismatik sehingga diketahui
model pengakuan hukumnya.


Studi ini bertujuan mencari model pengakuan pluralisme hukum yang ideal dalam negara kesatuan yang selama ini cenderung bersifat sentralistik seperti implementasi Undang-Undang Pokok Agraria mengabaikan hukum adat. Pendekatan Teori Prismatik hukum yang dihasilkan mampu memenuhi keadilan dalam masyarakat yang majemuk. Metode yang digunakan bersifat yuridis normatif melalui pendekatan politik hukum berbagai peraturan perundang- undangan dan menggunakan analisis kualitatif.

Hasil riset menunjukkan bahwa 1) Politik Hukum sebagai pedoman pembangunan hukum terjadi inkonsistensi tidak sesuai

Pancasila dan tata hukum yang mengakomodasi pluralisme hukum,akibatnya hukum adat tunduk kepada hukum nasional merupakan pengakuan pluralisme hukum yang lemah, 2) Model pengakuan pluralisme hukum nasional melalui pendekatan Teori Prismatik dengan memerhatikan kemajemukan tatanan hukum yang berlaku sehingga tercipta kepastian,kemanfaatan nilai keadilan dalam masyarakat sesuai ideologi dan Pancasila sebagai jiwa bangsa Rekomendasi berupa: 1) Pembangunan hukum menggunakan model pengakuan pluralisme hukum nasional melalui pendekatan Teori Prismatik agar tercipta kepastian, kegunaan dan nilai keadilan dalam masyarakat sesuai ideologi dan Pancasila sebagai jiwa bangsa, 2) Pendekatan Teori Hukum Prismatik dapat menjadi solusi alternatif model pengakuan pluralisme hukum dalam mewujudkan hukum nasional Indonesia berdasar Pancasila sebagai ideologi dan jiwa bangsa.

\section{Introduction}

Indonesia is a unitary state with highly plural national characteristics consisting of various islands, ethnic groups, religions, and cultures. This diversity through the motto "Bhinneka Tunggal Ika" (English: Unity in Diversity) is considered a strength. However, it can also be considered a weakness at the same time. Diversity may become a strength when it can create a feeling of nationality and unity. On the other hand, it will be a disaster if it contains the seeds of national disintegration, such as ethnicism and radicalism.

The choice of a unitary state characterized by laws that the central government makes must accommodate diversity, resulting in legal pluralism for local governments, both provincial and district/city governments. Constitutionally, the Indonesian government guarantees legal pluralism politics through a pluralistic legal system as regulated in Article 18B Section 2 of the 1945 Constitution of the Republic of Indonesia, which implies that the will of the state is related to laws that apply and continue to be developed (Jamin, 2015). The constitution recognizes and respects indigenous peoples and their traditional rights as long as they still exist. Furthermore, Article 28I Section 3 is related to the cultural identity and the rights of traditional communities being respected in line with the development of the era and civilization.

As long as they still exist, the diversity of customary laws that have grown and developed cannot just be ignored by state law. The diversity of law is a cultural identity, which is emphasized in Article 28 Section 3 of the 1945 Constitution. Therefore, it is clear that the Republic of Indonesia's constitution can be considered a pluralist constitution (Jamin, 2017).

Community resistance due to the marginalization of legal diversity can be seen in the case of filing a judicial review right against the Local Regulation of Bali Province regarding differences in understanding of local wisdom between the petitioners and the panel of judges (Atmaja, Gede Marhaendra Wija., Aryani, Nyoman Mas., Utari, Anak Agung Sri., Griadhi, 2017). The petitioners interpret that local wisdom in the form of customary law, which is commonly called Awig-awig, which still exists and is recognized by the local community around the temple, has regulated the 
sanctity of the temple which must be guarded and protected (Atmaja, Gede Marhaendra Wija., Aryani, Nyoman Mas., Utari, Anak Agung Sri., Griadhi, 2017). On the other hand, the panel of judges defines local wisdom as regional characteristics. In this case, the local wisdom contained in the Regional Regulation may regulate the area of the holy place, which is a respect for local wisdom. Another case is the recognition of the existence of local irrigation management institutions, especially in Java, called Ulu-ulu until currently, which is stipulated in Indonesia's Law No. 17/2019.

This represents the existence of state law intervention through co-optation. Those laws do not explicitly regulate the existence of local institutions, in which those local institutions are still alive and developing. However, state law does not fully recognize the existence of those local institutions (Nugroho, 2020).

For that reason, it indicates the existence of people's law which has existed since the colonial occupation era in Indonesia and is undoubtedly established in a country that is formed on various ethnic groups with their cultural diversity (Wahyuni, 2013). These different legal tensions often lead to horizontal and vertical conflict resistance. To date, real legal conflicts and examples have been mentioned above. Those conflicts are in the form of conflicts between customary law and state law due to the state not recognizing the existence of people's law, especially concerning agrarian law. Agrarian conflicts are due to unilateral claims from the state that people's laws must comply with state laws, even though Indonesia's Law No. 5/1960 (Basic Agrarian Law) clearly recognizes the rights of customary communities in control of land and natural resources.

The politics of national law in Indonesia's Law No. 17/2007 concerning the Long-Term National Development Plan for 2005 - 2025 must be able to accommodate legal needs. Factual-based national law development applies not only to laws made and enforced by the state but also to unwritten laws, often called non-state law or living law (Jamin, 2017). State law is not the only form of law that applies in society.

Law is required to play a role beyond the normative limits of regulations to touch the root of the problem. An interdisciplinary and pluralistic approach is needed because the problem of legal pluralism within the framework of a unitary state can be resolved by positive law enforcement that emphasizes the value of legal certainty and social resolution that promotes justice.

In its development, the concept of a prismatic model society lies between the two extreme poles in Indonesia, where Indonesia is proclaimed as the state of law. This state is in a continuum of traditional or centralized society and modern or scattered society based on Pancasila and the 1945 Constitution, which adopts the prismatic or integrative concept of the two concepts. Therefore, the principles of legal certainty and rechsstaat must be combined with the principle of justice in the rule of law. According to F.W. Riggs (Mahfud, 2006), a prismatic society is a community unit that is built by integrating various interests. For that reason, it is necessary to find a model for recognizing legal pluralism in a unitary state that has tended to be centralized and ignore customary law, in the hope of being able to fulfill justice in a pluralistic society.

\section{Methodology}

The approach applied in this study was normative-juridical through research on norms, in the form of ordinary principles and legal principles, and statutory regulations in the 1945 Constitution that regulate the implementation that governs customary law or local wisdom (Mukti Fajar ND., 2013). This study was conducted by analyzing data qualitatively on statutory regulations concerning vertical synchronization to Pancasila and the 1945 Constitution.

This study employed a conceptual approach, a statute approach, and a historical approach to obtain the expected scientific truth. Secondary data, besides statutory regulations, are judicial decisions, the findings of the previous studies, and field research as confirmation material. 


\section{Results and Discussion}

1. Consistency of Legal Politics in National Law Development based on Pancasila and Legal System that Accommodates Legal Pluralism

\section{a) Pluralism of State Law in a Unitary State based on the 1945 Constitution}

Legal pluralism means the diversity of laws and the presence of more than one legal rule in a social environment. Legal pluralism criticizes the ideology of legal centralism. This idea serves as a concept that is developed together with the development of anthropology (Griffiths, 1986).

The development of legal thinking is considered modern law when state law possesses its uniqueness, placing state law above other legal principles, such as customary law, religious law, and customs. These legal principles are considered to have weaker binding power and must comply with state law (Griffiths, 1986).

The consequence of the principle of constitutionalism is the limitation of the power of state administrators, which is a part of the needs of the people through the constitution (Imam Ropii, 2017). Legal pluralism is the answer to deficiencies found in the perspective of the national legal system in Indonesia which tends to be centralized (Wahyuni, 2013).

Erman Radjagukguk argues that legal pluralism is defined as a situation where there are two or more legal systems in social life (Imam Ropii, 2017). The heterogeneity of society has its respective legal system which differs from one another as a unit for every homogeneous society. Community legal pluralism must be accepted as a reality in line with the pluralism of society itself, considering that community law is one of its products.

The plurality of the Indonesian people is expressed by the slogan "Bhinneka Tunggal Eka" (English: Unity in Diversity). The deductive reflection on the reality of induction (plurality) of this nation guarantees and protects all of its components in the nation's constitution (FHUKUM UNPATTI, 2021).

Related to the recognition and respect for plurality in a juridical constitutional manner, the 1945 Constitution Article 18B Section 2 reveals that the state recognizes and respects indigenous peoples and their traditional rights as long as they are alive and in line with the development of society and the principles of the Unitary State of the Republic of Indonesia. Furthermore, Article 28I Section 3 shows that the cultural identity and rights of traditional communities are respected in line with the times and civilizations. Therefore, Indonesia as a unitary state is in line with the mandate of the constitution and values that support the nation's social and spiritual life order, which influences the character and characteristics of the Indonesian people and nation, reflected in Pancasila.

\section{b) The Consistency of Political Direction of National Law Development}

The long-term development direction is regulated in Indonesia's Law No. 17/2007 concerning the National Long-Term Development Plan (Indonesian: Rencana Pembangunan Jangka Panjang Nasional (RPJPN)) for 2005-2025. In the national development planning document for a period of 20 years from 2005 to 2025, Chapter IV Point C states that the realization of Indonesia as a democratic state based on law and justice will emphasize the following.

1) Establishing the rule of law and the enforcement of human rights rooted in Pancasila and the 1945 Constitution of the Republic of Indonesia reflect the truth, justice, accommodation, and aspirations.

2) Creating a constitutional foundation to strengthen democratic institutions.

3) Strengthening the role of civil society and political parties in political life.

4) Strengthening the institutionalization of democratic values that emphasize the principles of tolerance, non-discrimination, and partnership.

5) Realizing the consolidation of democracy in various aspects of political life which can be measured by the existence of a government based on law, a professional and neutral bureaucracy, civil 
society, independent political and economic society, and the reinforcement of national independence.

According to Satjipto Rahardjo (Satjipto Rahardjo, 1991), legal politics means how to choose activities and methods to be used to achieve certain social and legal goals in society (state). From various definitions of legal politics, it can be concluded that legal politics serves as a guideline and blueprint regarding the law that will be developed concerning the

substantial aspects of the regulations, the process of making it (law-making), law enforcement, law implementation, and legal community development. Related to the direction of the development in Indonesia's Law No. 17/2007 Chapter IV.1 Letter E Number

6 , it points out that legal development is directed at realizing a solid national legal system based on Pancasila and the 1945 Constitution of the Republic of Indonesia, in which legal development is carried out through legal reform while taking into account the plurality of the prevailing legal order.

Therefore, Pancasila as the basis of state philosophy objectively comes from the perspective of life and philosophy of life of the Indonesian people that have existed in the nation's history. The values contained in Pancasila are a crystallization of values that are believed to be true. Therefore, the affirmation of Bhineka Tunggal Ika in the constitution must be accepted and recognized so that the unification of law declared in various legal development policies needs to be reviewed.

\section{National Legal Pluralism Recognition Model Through Prismatic Theory Approach a. Indonesian Prismatic Society and the Basic Values of Pancasila}

The Pancasila legal system is different from the Continental European and Anglo-Saxon legal systems because it is a legal integrative between the Continental European and Anglo- Saxon legal systems by taking the best aspects from Rechtstaat (Continental Europe) and The Rule of Law (Anglo-Saxon), which contain a prismatic and integrative link between the principles of legal certainty and substantial legal justice. Pancasila accommodates good elements from the viewpoint of individualism and collectivism, in which human beings as individuals have rights and human freedoms. However, at the same time, they are attached to human obligations as God's creatures and social beings, which is reflected in the concept of a state of the law in the Post Amendment of the 1945 Constitution.

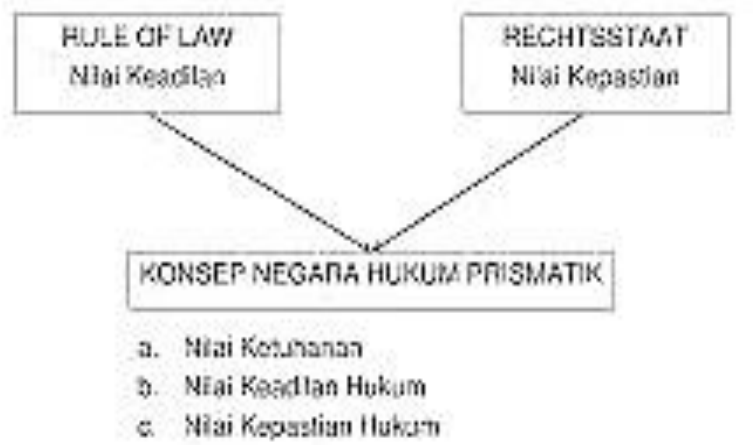

For legal development in Indonesia, the evolutionary process shows imperfect changes. F. W. Riggs pictorially describes the development. He depicts it by making the metaphor of light refracted through a prism. The development of a society can be happening by moving away from the welldivided structure of society, meaning that the primary functions have not yet obtained their autonomy or perfect internal differentiation. Riggs uses this kind of prism metaphor to describe a society that is at the same time a field for the operation of original and modern structures. This society is called by Riggs a prismatic type of society (Satjipto Rahardjo, 2009). 


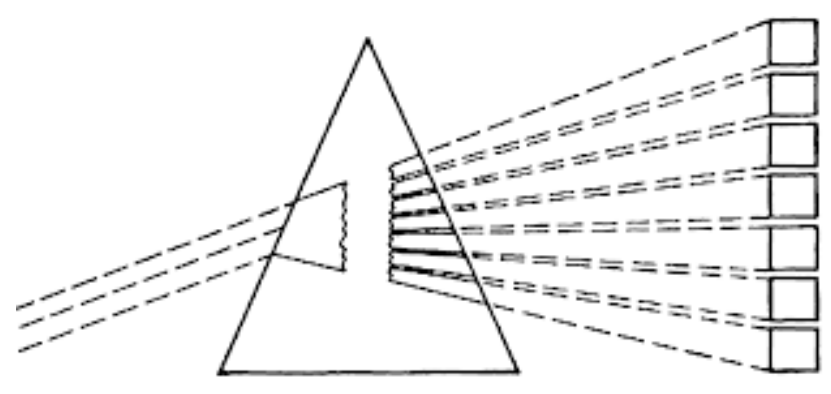

PRISMATIC

DIFFRACTED

Prismatic Society - Transitional Society by Fred W. Riggs

Legal diversity or legal pluralism, as long as it is based on reality, should not be dismissed for granted, especially if this is interpreted as a cultural identity, as emphasized in Article 28 Section 3 of the 1945 Constitution. Therefore, it can be concluded that the constitution of the Republic of Indonesia is a pluralist constitution.

\section{b. Several Cases of Conflict Resolution between National Law and Customary Law or Local Wisdom in Seeking Justice}

For the first case, the Decision of the Supreme Court No. 65P/HUM/2013 regarding the Case for Objection of the Judicial Right to the Bali Provincial Regulation No. 16/2009 concerning the Bali Provincial Spatial Plan for 2009-2029 (hereinafter referred to as PUMA 65 P/HUM/2013) rejected the petitioners' petition for objection to judicial rights. There are differences in understanding of local wisdom between the petitioners and the panel of judges (Atmaja, Gede Marhaendra Wija., Aryani, Nyoman Mas., Utari, Anak Agung Sri., Griadhi, 2017).

On the one hand, the petitioners interpret local wisdom as customary law, commonly called Awig-awig which lives and is recognized by the community around the temple, which has regulated the sanctity of the temple that must be guarded and protected. On the other hand, the panel of judges defines local wisdom as regional characteristics contained in Regional Regulations that govern sacred areas, which are respect for local wisdom.

Constitutional denial is mandated in Article 18B Section 2 in conjunction with Article 28I Section 3 of the 1945 Constitution of the Republic of Indonesia, which is a marker of the 1945 Constitution as the pluralist constitution. However, the decision of the Supreme Court that was stipulated by the panel of judges in the Case for the Objection of the Judicial Right to the Bali Provincial Regulation No. 16/2009 concerning the Bali Provincial Spatial Plan for 2009-2029 by considering the last decision (PUMA 65 P/HUM/2013) was different from the previous decision in formulating legal considerations.

For the second case, the Special Autonomy for Papua Province (Jamin, 2014) is basically the granting of wider special powers to the Papua Province to regulate and manage the interests of the local community based on the aspirations and basic rights of the Papuan people (Article 1 Letter $b$ of the Special Autonomy Law). Through special autonomy, Papua has broad powers, covering all government areas (except foreign policy, security, monetary \& fiscal, religion, and justice).

The Papua Special Autonomy Law indicates the recognition of customary courts for customary law communities in Papua Province. This recognition is regulated in Chapter XIV concerning the Powers of the Jurisdiction in Article 509 and Article 510. Article 50 of Law No. 21/2001 concerning Special Autonomy for Papua Province states as follows. (1) Judicial power in Papua Province shall be exercised by the Judiciary under statutory regulations. (2) Apart from the judicial power as referred to in Section 1, it is recognized that there is a customary court within certain customary law communities. However, the customary judiciary institution is placed under the sub-ordinance of the state court so that it is not autonomous and not independent. Furthermore, all decisions can be overturned by the state judiciary which examines, and re-tries disputes or cases (Jamin, 2014) 
For the third case, the irrigation management by Ulu-ulu in East Java shows the effectiveness of the law in the irrigation management institution of the Water-Using Farmer Association (Indonesian: Himpunan Petani Pemakai Air (HIPPA)) in Lumajang, East Java. This represents the state's legal recognition of the existence of local wisdom institutions based on Article 18B Section 2 of the 1945 Constitution to achieve the prosperity of the Indonesian people (Article 33 Section 3 of the 1945 Constitution). However, the implementing regulations are still limited to discriminatory recognition (Nugroho, 2018).

Government agencies structurally manage irrigation management from central to regional governments, including HIPPA at the lowest level with the management composition (HIPPA administrators, Ulu-ulu as technical executors, and head of tertiary blocks or compartments) members. Culturally, the presence of the institution called Ulu-ulu as a manifestation of local wisdom dealing with state law shows the inability of HIPPA in irrigation management. The legal culture in the form of mutual cooperation embodies the authority of irrigation management that provides social justice for water-using farming communities.

From the three cases aforementioned, it seems that the legal pluralism approach to solving problems occurring in the local community is highly relevant. The legal pluralism approach does not merely see local law as a reality or law as a social reality (Kleinhans \& Macdonald, 1997). The establishment of people's law (local wisdom) is based on the spirit and experience of social interaction at the local level, as can be seen in communities in Papua (customary courts), Java (local wisdom in irrigation management), and Bali (Awig-awig).

There are 2 types of legal pluralism according to Griffiths, namely (1) weak legal pluralism, characterized by other forms of legal centralism, which is acknowledging the existence of legal pluralism but considering state law as superior law, and (2) strong legal pluralism, indicating the presence of a plurality in legal arrangements that exist in all groups of society, in which all existing legal systems are considered equal in society, and do not show a legal system hierarchy (TIM Huma, 2005). Those three presented cases indicate that national law's recognition of legal pluralism is still weak.

Pancasila plays a major role as a value system for the nation's life and has at least four guiding principles that must be used as guidelines in the establishment and enforcement of law in Indonesia, namely as follows.

(1) The law must protect the entire nation and guarantee the nation's integrity.

(2) Therefore, there should be no law that implants the seeds of disintegration.

(3) The law must guarantee social justice by providing special protection for the weak so that they are not exploited in free competition against the strong.

(4) The law must be developed democratically while building democracy in line with the nomocracy (rule of law).

(5) The law must not be discriminatory and must be based on humanity.

Law is like a language. It grows and develops in a nation and becomes the common property of that nation. Therefore, the law must be based on the character and national spirit of the concerned nation (volkgeist).

\section{c. The Prismatic Theory Approach as a Legal Pluralism Recognition Model}

The prismatic legal theory takes into account the plurality of the prevailing legal order and the effects of globalization as an effort to increase legal certainty and protection, law enforcement, and human rights. Prismatic law is a concept in which the best values from social norms are extracted, although some of these values may conflict when combined into one concept. Prismatic law is needed in Indonesia because prismatic societies have been formed in Indonesia due to overlapping or substantially interdependent structures and heterogeneity. 
Therefore, in prismatic law, the legal pluralism recognition model includes all of the following: (1) heterogeneity, where there are differences and combinations between traditionality and modernity, (2) formalism, where there are differences between formal rules and the implementation of these rules, and (3) redundancy of life, where there is a different and special treatment between formal groups and informal groups (Suryawan, 2021).

Because the structure of Indonesian society tends to be prismatic, prismatic laws can be created to meet the needs of society. Riggs (Suryawan, 2021) argues that today's society is living in a transition from traditionality to modernity. Therefore, there must be a combination of the two concepts.

Riggs distinguishes society into three groups: modern society, traditional society, and prismatic society in which traditionality and modernity co-exist. Prismatic law combines many different elements to take the best concept from each element to create new and reliable concepts.

The theory is similar to that put forward by Moh. Mahfud MD (Suryawan, 2021) that the prismatic concept includes many principles, many concepts, and various traditions and is applicable in different fields. The prismatic concept is suitable to be applied in Indonesia because the basis of Indonesian society is a prismatic society. A prismatic legal framework is based on Pancasila with the following considerations.

(1) Pancasila contains good elements from the viewpoint of individualism and collectivism, in

(2) which humans have human rights, freedoms, and obligations as creatures of God and as social beings.

(3) Pancasila integrates the concept of rechtsstaat, which emphasizes civil law and legal certainty and the concept of the rule of law which emphasizes common law and a sense of justice.

(4) Pancasila accepts law as a tool for community reform (law as a tool of social engineering)

(5) as well as a reflection of the sense of justice that lives in society (living law).

The prismatic theory approach is very suitable for applying to the Unitary State of the Republic of Indonesia which is built on a plurality of tribes, cultures, community laws, languages, and others. Therefore, this nation should be developed and maintained based on plurality based on the conditions \& development of this nation in the future and the ideology of Pancasila which comes from the Indonesian nation itself (Imam Ropii, 2017).

\section{Conclusion}

From the study described above, it can be concluded that the recognition model for national legal pluralism through the prismatic theory approach is as follows.

1) Political law as a guideline for legal development experiences inconsistencies that are not in line with Pancasila and legal systems that accommodate legal pluralism because it still places state law in a higher position than customary law. As a result, customary law is subject to national law, acknowledging weak legal pluralism.

2) The recognition model for national legal pluralism through the prismatic theory approach by paying attention to the plurality of the prevailing legal order and the effects of globalization as an effort to increase legal certainty and protection, law enforcement and human rights must be based on the value of justice in society according to the ideology of Pancasila as the soul of the nation.

Recommendations from this study are as follows.

1) The prismatic legal theory needs to be continuously studied and considered in developing law so that national law can accommodate various plural community interests in various laws and regulations. 
2) The prismatic legal theory approach can be an alternative solution to the recognition model of legal pluralism in realizing Indonesian national law based on Pancasila as the ideology and spirit of the nation.

\section{References}

Atmaja, Gede Marhaendra Wija., Aryani, Nyoman Mas., Utari, Anak Agung Sri., Griadhi, N. M. A. Y. ni. (2017). PLURALISME KONSTITUSIONAL DALAM PENGAKUAN KESATUAN MASYARAKAT HUKUM ADAT: Studi Interpretasi atas Putusan Mahkamah Agung dalam Perkara Permohonan Keberatan Hak Uji Materiil terhadap Peraturan Daerah Provinsi Bali Nomor 16 Tahun 2009. Yogyakarta: PENERBIT ANDI.

FHUKUM UNPATTI. (2021). BHINEKA TUNGGAL IKA DALAM BINGKAI NEGARA KESATUAN REPUBLIK INDONESIA. https://webcache.googleusercontent.com/search?q=cache:02v3OK14cnoJ:https://fhukum.unp atti.ac.id/bhineka-tunggal-ika-dalam-bingkai-negara-kesatuan-republikindonesia/ $+\& \mathrm{~cd}=1 \& \mathrm{hl}=\mathrm{id} \& \mathrm{ct}=\mathrm{clnk} \& \mathrm{gl}=\mathrm{id}$

Griffiths, J. (1986). What is legal pluralism? Journal of Legal Pluralism and Unofficial Law, 18(24), 1-55. https://doi.org/10.1080/07329113.1986.10756387

Imam Ropii. (2017). PENGHORMATAN PLURALITAS HUKUM MASYARAKAT DALAM BINGKAI HUKUM NASIONAL SEBAGAI SARANA MENEGUHKAN INTEGRASI BANGSA. Jurnal Prasada, 4 (1), 37-49. https://doi.org/10.22225/jhp.4.1.156.12-21

Jamin, M. (2014). Peradilan Adat: Pergeseran Poltik Hukum, Perspektif Undang-Undang Otonomi Khusus Papua. Universitas Brawijaya.

Jamin, M. (2015). Politik Hukum Pengakuan Kesatuan Masyarakat Hukum Adat di Indonesia. Surakarta: UNS Press.

Jamin, M. (2017). TEORI HUKUM PRISMATIK SEBAGAI IHKTIAR MEWUJUDKAN PLURALISME HUKUM NASIONAL DI INDONESIA. Jurnal Prasada, 4(1), 50-59. https://doi.org/10.22225/jhp.4.1.159.50-59

Kleinhans, M. M., \& Macdonald, R. A. (1997). What is a Critical Legal Pluralism? Canadian Journal of Law and Society, 12(2), 25-46. https://doi.org/10.1017/S0829320100005342

Mahfud, M. (2006). POLITIK HUKUM MENUJU PEMBANGUNAN SISTEM HUKUM NASIONAL. Makalah Seminar Arah Pembangunan Hukum. ???\%0Ahttp://repositori.usu.ac.id/handle/123456789/3673

Mukti Fajar ND., Y. A. (2013). Dualisme Penelitian Hukum Normatif \& Empiris. Yogyakarta: Pustaka Pelajar. http://library.umy.ac.id/koleksi/view/64762/DualismePenelitian-Hukum-Normatif--Empiris

Nugroho, J. (2018). Perubahan Paradigma Hukum Pengelolaan Sumber Daya Air Berdasarkan Prinsip Keadilan Sosial (Studi Bekerjanya Hukum di Masyarakat Petani Pemakai Air di Kabupaten Lumajang Jawa Timur). Universitas Brawijaya.

Nugroho, J. (2020). Pergeseran Paradigma Hukum Pengelolaan Sumber Daya Air Dan Pengaruhnya Terhadap Pengakuan Kelembagaan Lokal Berdasarkan Prinsip Keadilan (Perspektif Sejarah Hukum). Transparansi Hukum, 3(1), 66-83. https://doi.org/10.30737/transparansi.v3i1.668 Satjipto Rahardjo. (1991). Ilmu Hukum Edisi Revisi (Terbaru). Bandung: Citra Aditya Bakti. Satjipto Rahardjo. (2009). Hukum Dan Perubahan Sosial. Suatu Tinjauan Teoritis serta Pengalaman - Pengalaman Di Indonesia. Yogyakarta: Genta Publishing.

Suryawan, I. (2021). Konsepsi Hukum Indonesia yang bersifat Prismatik.

TIM Huma. (2005). Pluralisme Hukum Sebuah Pendekatan Interdisiplin. Jakarta: FF Huma.

Wahyuni, D. S. (2013). Pluralisme Hukum dalam Pembangunan Hukum Indonesia: Masalah dan Tantangan Ke Depan. Konferensi Asosiasi Filsafat Hukum Nasional (AFHI) Ke-3 Di Universitas Airlangga Surabaya. 